\title{
Diagnosis of Trichomoniasis in Male Patients on Performing Nested Polymerase Chain Reaction
}

\author{
Erkek Hastalarda Trichomoniasis Tanısında Polimeraz Zincir Reaksiyonu (Pzr) Kullanımının \\ Etkinliğinin Araştırılması
}

\author{
T. Mutlu Yar ${ }^{1}$, Mehmet Karakuş², Seray Töz², Aysun Bay Karabulut ${ }^{2}$ Yusuf Özbel², Metin Atambay \\ 'Department of Parasitology, Turgut Özal Medical Center, İnönü University Faculty of Medicine Malatya, Turkey \\ 2Department of Parasitology, Ege University Faculty of Medicine, İzmir, Turkey \\ ${ }^{3}$ Department of Biochemistry, Turgut Özal Medical Center, İnönü University Faculty of Medicine Malatya, Turkey
}

Cite this article as: Yar TM, Karakuş M, Töz S, Bay Karabulut A, Özbel Y, Atambay M. Diagnosis of Trichomoniasis in Male Patients on Performing Nested Polymerase Chain Reaction. Türkiye Parazitol Derg 2017; 41: 130-4.

\section{ABSTRACT}

Objective: Trichomoniasis is a parasitic infection that occurs with the settlement of Trichomonas vaginalis in female and male urinary and reproductive tracts. This infection is generally asymptomatic in males, and males are thought to be a carrier for the transmission of infection. In this study, our aim was to detect trichomoniasis using nested polymerase chain reaction among males who were referred to a hospital with suspected urinary tract infection.

Methods: Urine samples were collected from 138 male patients between 18 and 50 years of age who were referred with suspected urinary system infection to the Urology Outpatient Clinic at Malatya University Medical Center Malatya between December 2013 and May 2014. Direct microscopy, two different culture methods, and nested Polymerase chain reaction (PCR) were performed for the investigation of $T$. vaginalis in urine samples.

Results: Urinary tract infection was diagnosed in 47 of the 138 patients according to white and red blood cell counts in the urine samples. T. vaginalis infection was detected in 6.5\% (9/138) of the suspected patients by nested PCR, while none of the samples tested positive by direct microscopy and culture examinations. Statistical significance was found between infection of the urinary tract and nested PCR positivity for T. vaginalis. Conclusions: According to our results, nested PCR is the most sensitive method for the detection of trichomoniasis in male patients. We strongly recommend using nested PCR for the differential diagnosis of urinary infections in males.

Keywords: Trichomonas vaginalis, direct microscopy, culture, nested PCR

Received: 09.08.2016

Accepted: 20.06 .2017

\section{ÖZ}

Amaç: Kadın ve erkekte idrar ve üreme yollarında Trichomonas vaginalis'in yerleşmesi ile oluşan parasite infeksiyon Trichomoniosis olarak adlandırılır. Erkeklerde bu infeksiyon büyük çoğunlukla asemptomatik seyretmekte ve parazitin bulaşmasında taşıyıcı rolü üstlendikleri düşünülmektedir. Bu çalışmada trichomoniosis tanısı koyulmayan erkeklerdeki gizli taşıyııılığı Nested Polimeraz Zincir Reaksiyonu (PZR) yöntemi ile açığa çıkarmak amaçlanmıştır.

Yöntemler: Çalışmada Malatya İnönü Üniversitesi Tıp Fakültesi Turgut Özal Tıp Merkezi'ne Aralık 2013-Mayıs 2014 tarihleri arasında idrar yolu infeksiyonu ön tanısı ile Üroloji Polikliniğine başvuran 18-50 yaş arası 138 erkek hastadan idrar örnekleri; direct mikroskobik bakı, kültür ve Nested PZR yöntemleri ile incelenmiştir.

Bulgular: Direkt mikroskobi ve kültür yönteminde T. vaginalis'e rastlanılmazken, Nested PZR yöntemi ile \%6,5 (9/138) hastada T. vaginalis DNAsı pozitif bulunmuş ayrıca pozitif bulunan hastalar ile idrar yolu infeksiyonu arasındaki ilişki de istatiksel açıdan anlamlı bir farklılık olduğu tespi tedilmiştir. Sonuç: T. vaginalis ile enfekte erkeklerin çoğunda semptom bulunmadığı için T. vaginalis araştırılması açısından gözardı edildiği, gizli taşıyıcı olarak hastalığı yaymaya devam ettikleri, T. vaginalis'in saptanmasında Nested PZR yönteminin çok hassas ve gizli taşıyıcıları açığa çıkarmak amacıyla tanıda mutlaka kullanılması gereken bir yöntem olduğu kanısına varıımıştır.

Anahtar Kelimeler: T. vaginalis, infeksiyon, direktmikroskobi, kültür, Nested PZR

Geliş Tarihi: 09.08.2016

Kabul Tarihi: 20.06.2017

Address for Correspondence / Yazışma Adresi: Mutlu Yar, E.mail: mutluyaraycan@gmail.com DOI: $10.5152 /$ tpd.2017.5016

(OCopyright 2017 Turkish Society for Parasitology - Available online at www.tparazitolderg.org

OCTelif hakkı 2017 Türkiye Parazitoloji Derneği - Makale metnine www.tparazitolderg.org web sayfasından ulaşılabilir. 


\section{INTRODUCTION}

Trichomonas vaginalis is an important and curable sexually transmitted infection (STI), and worldwide, the number of people estimated to have this infectionis 187 million adults (15 to 49 years of age) (1). T. vaginalis infection causes vaginitis and cervicitis with profuse, frothy vaginal discharge and dysuria; pelvic inflammatory disease; preterm birth; and low-birth weight babies in women and urethral discharge (non-gonococcal urethritis), which is often asymptomatic and can be associated with prostatitis, epididymitis, and male factor infertility, in men. In addition, T. vaginalis infection has been implicated as a significant risk factor in the sexual transmission of human immunodeficiency virus (HIV) and other possible bacterial and viral STIs as well as of cervical cancer (2-5).

There are limited studies on trichomoniasis among female and male patients in Turkey. T. vaginalis was found in 8 (7\%) of 116 women (114 and 2 were in the reproductive and postmenopausal periods, respectively) showing nonspecific vaginal discharge during their gynecological examination by microscopy and the cysteine-peptone-liver-maltose (CPLM) culture method (6). A total of 253 women (aged from 20 to 48 years) with abnormal vaginal discharge who applied to the Obstetrics and Gynecology outpatient clinic were enrolled, and 22 (8.69\%) trichomoniasis cases were detected by performing a direct native examination and Giemsa staining (7).

T. vaginalis infection in male urine samples was diagnosed in 3 (2.7\%) and $1(0.9 \%)$ out of 110 patients with urethritis and control group without any symptoms admitted to the urology clinic by direct microscopical examination of the centrifuged urine samples, respectively (8).

Urine samples of 768 male patients were examined for T. Vaginalis infection by microscopy, and 3 patients $(0.2 \%)$ were found to be positive (9). Urethral discharge in 85 male patients with non-gonococcal urethritis was investigated for $T$. vaginalis infection, and 5 (5.8\%) and 2(1.4\%) positive results were found on performing microscopy and trypticase-yeast extract-maltose (TYM) culture, respectively (10). Urethral discharge and urine sediments of 100 male patients with non-gonococcal urethritis were examined for T. vaginalis infection, and 12 (12\%) and 4 (4\%) positive results were found, respectively. None of the samples showed positivity on performing CPLM culture (11).

Trichomoniasis is usually asymptomatic or shows nonspecific clinical symptoms; worldwide, diagnosis based on laboratory test results is crucial for the treatment and control of the disease (2). Conventional diagnostic techniques involved direct examination of the parasite and CPLM and TYM culture methods. Culture methods are time consuming; they have lower sensitivity than other diagnostic methods and are not standard suitable tests in routine diagnostic laboratories. Direct microscopy of the parasite is a cheap, fast, and sensitive method but requires vaginal or urethral discharge samples and an examination to be performed immediately. Because of all these reasons, there is a requirement for sensitive, time-independent, standard tests using noninvasive sampling for diagnosing trichomoniasis. In recent years, techniques using Polymerase chain reaction (PCR) have provided new approaches to increase the sensitivity as well as to use noninvasive body fluids such as urine $(2,3,12-14)$. In the present study, we aimed to detect $T$. vaginalis infection in urine samples obtained from males by performing nested PCR and to compare the results with those obtained using conventional methods.

\section{METHODS}

\section{Sampling}

Samples were collected from 138 males who were admitted to the Urology Outpatient Clinic in Medical Faculty Turgut Özal Center of Malatya Inönü University located in Malatya between December 2013 and May 2014. The inclusion criteria were (i) males between 18 and 50 years of age, (ii) complaints related to the urinary tract, and (iii) biochemical analyses of urine (counts of white and red blood cells). Two tubes of urine samples were collected from the patients: one for direct examination and the other for culture inoculation.

Urinary tract infection criteria: The presence of more than five leucocytes with more than three erythrocytes in urine sediments of the patients in a high-power $(400 \times)$ microscopic field was accepted as urinary tract infection (15-16).

Ethical permission was provided from Malatya University Medical Faculty Ethical Committee (protocol no: 2013/149), and urine biochemical analysis data of the patients were obtained from hospital records.

\section{Direct microscopy and culture}

Wet mount preparations of urine samples of the patients were prepared immediately from first-void urine samples after centrifuging at $400 \mathrm{rpm}$ for $5 \mathrm{~min}$, and sediments were examined under a $40 \times$ objective for the detection of $T$. vaginalis trophozoites.

Cysteine-peptone-liver-maltose and TYM cultures were prepared according to the previous literature (17). At least $1 \mathrm{ml}$ of the urine sediment was inoculated into both culture tubes and was incubated at $37^{\circ} \mathrm{C}$ for a week. Then, tubes were examined every 2 days for the presence of T. vaginalis infection.

\section{DNA isolation}

First-void urine samples were centrifuged at $8000 \mathrm{rpm}$ for $10 \mathrm{~min}$, and the pellet was stored at $-20^{\circ} \mathrm{C}$ until DNA was isolated. After dissolving the pellet under room temperature, DNA was isolated using a Qiagen DNA Easy Blood \& Tissue kit (Hilden, Germany) according to the manufacturers protocol and was stored at $-20^{\circ} \mathrm{C}$ until Nested PCR was performed.

\section{Nested PCR}

Before the experiments, the PCR protocol was optimized using DNA obtained from a local T. vaginalis isolate. The first (TVC3F/ TVC4R) and second PCR (TVC11F/ TVC12R) primer sets were used as previously reported (2). PCR was performed using readyto-use master mix (Nano Helix Co., Ltd. Helix Amp ${ }^{T M}$ ) with 20 ng of DNA and $10 \mathrm{pmol}$ of each primer. PCR conditions were as follows: $95^{\circ} \mathrm{Cfor} 2 \mathrm{~min}$, followed by 35 cycles of $20 \mathrm{~s}$ at $95^{\circ} \mathrm{C}, 40 \mathrm{~s}$ at $50^{\circ} \mathrm{C}, 40 \mathrm{~s}$ at $72^{\circ} \mathrm{C}$, and $5 \mathrm{~min}$ at $72^{\circ} \mathrm{C}$. PCR products were visualized after performing gel electrophoresis on GelRed ${ }^{\mathrm{TM}}$-stained $1.2 \%$ agarose gel. The detection of band in $237 \mathrm{bp}$ was accepted to be positive. To eliminate DNA contamination, PCR, DNA isolation, and gel electrophoresis were performed in separate rooms.

\section{Statistical analysis}

Statistical associations between positivity and urinary tract infection were determined by applying Fisher's exact test. 


\section{RESULTS}

Totally, 138 males were included; their mean age was average 36 years. According to the biochemical analyses of the urine sediment, 47 of the 138 patients tested positive for urinary tract infection.
We could not detect any T. vaginalis trophozoites by direct microscopy and culture methods, whereas $237 \mathrm{bp}$ bands were observed in gel electrophoresis by nested PCR in 9 of the 138 patients (6.5\%) (Figure1). Fisher's exact Test results revealed a significant relationship between urinary tract infection and nested PCR positivity ( $p=0.003$ ) (Table 1 and 2 )
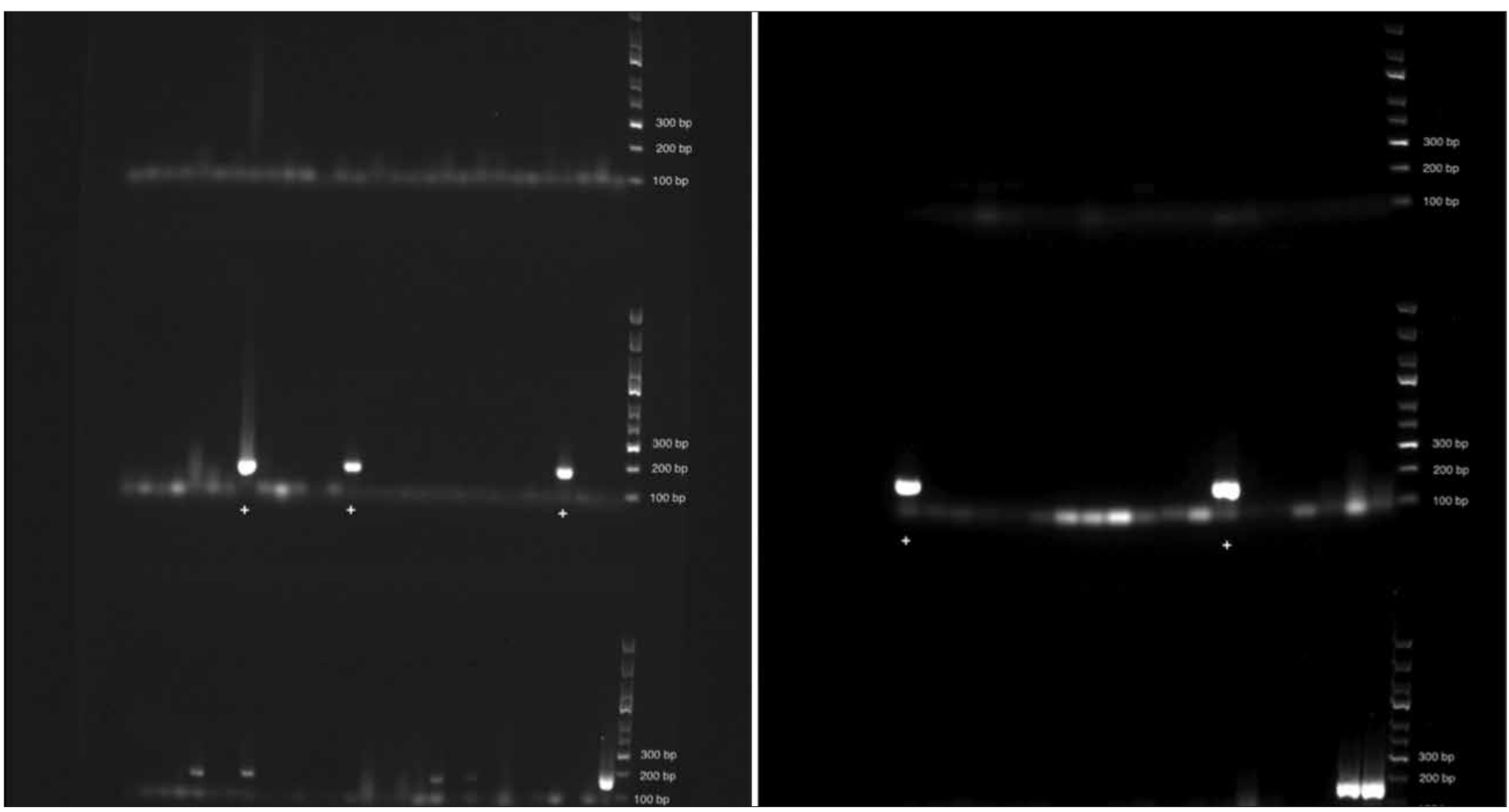

Figure 1. Nested Polymerase chain reaction gel electrophoresis showing in trichomoniasis-positive urine samples

Table 1. Results of patients positive for Trichomonas vaginalis infection

\begin{tabular}{|c|c|c|c|c|c|c|}
\hline Patient No & Age & Direct Microscopy & Culture & PCR & Leucocyte/HPF & Erythrocyte/HPF \\
\hline 37 & 49 & NEG & NEG & POS & 271 & 12 \\
\hline 43 & 34 & NEG & NEG & POS & 35 & 43 \\
\hline 55 & 25 & NEG & NEG & POS & 965 & 28 \\
\hline 63 & 32 & NEG & NEG & POS & 49 & 33 \\
\hline 66 & 18 & NEG & NEG & POS & NEG & NEG \\
\hline 77 & 48 & NEG & NEG & POS & 306 & 14 \\
\hline 79 & 41 & NEG & NEG & POS & 25 & 5 \\
\hline 105 & 46 & NEG & NEG & POS & 125 & 38 \\
\hline 117 & 28 & NEG & NEG & POS & 3 & 7 \\
\hline
\end{tabular}

Table 2. Relationship between nested PCR and urinary tract infection

\begin{tabular}{|l|c|c|c|c|}
\hline & & & \\
& & & \\
& & Negative (\%) & Positive (\%) & Total (\%) \\
\hline Nested PCR & Negative (\%) & $89(69.5)$ & $40(30.5)$ & $129(100)$ \\
\hline & Positive (\%) & $2(20.0)$ & $7(80.0)$ & $9(100)$ \\
\hline Total & & $91(65.9)$ & $47(34.1)$ & $138(100)$ \\
\hline PCR: Polymerase chain reaction
\end{tabular}




\section{DISCUSSION}

The estimation of the total number of new patients with important STIs such as Chlamydia trachomatis, Neisseria gonorrhoeae, and Trichomonas vaginalis infections and syphilis between the ages of 15 and 49 years showed that trichomoniasis is the most abundant infection globally (1).

The infection is reported to be asymptomatic in 70 to $80 \%$ of infected men; in those with symptoms, urethral discharge and dysuria are the main symptoms (4-5). Techniques for PCR have been developed to detect T. vaginalis infection in women; however, the detection of $T$. vaginalis infection in men by PCR has received less attention. Urine-based PCR assays for men have been described and PCR of urine samples from men was found to be much more sensitive than culture methods for detecting $T$. vaginalis infection. PCR screening of $T$. vaginalis infection among men with recurrent lower urinary tract symptoms was strongly recommended as a part of public health initiatives to control trichomoniasis (3).

There are limited studies on trichomoniasis among female and male patients in Turkey. T. vaginalis infection was found 4.5\%, $7 \%$, and $8.69 \%$ among women with vaginal discharge by conventional methods such as microscopy and culture in Turkey (36-7). T. vaginalis infection was diagnosed in $2.7 \%$ and $0.9 \%$ male patients with urethritis and in an asymptomatic control group by microscopy of centrifuged urine samples, respectively (8). Similarly, $0.2 \%$ of urine samples of male patients were found to be positive by microscopy (9). However, positivity rates of $5.8 \%$ and $1.4 \%$ were revealed by microscopy and culture methods using urethral discharge of male patients with non-gonococcal urethritis, respectively (10). Similarly, urethral discharge and urine sediments of male patients with non-gonococcal urethritis showed positivity rates of $12 \%$ and $4 \%$, while none of the samples tested positivity by the culture method (11). In the present study, urine samples were chosen as their collection is a non-invasive sampling method and nested PCR was performed as a sensitive and specific method; our results were compared with those of conventional methods such as microscopy and culture method. We found no positivity using microscopy and culture methods, but a positivity rate of $6.5 \%$ was detected by performing nested PCR, which is comparable with other results obtained in previous studies that used urethral discharge and/or urine samples. To our knowledge, our study is the first on trichomoniasis among male patients in Malatya, Turkey. In a previous study in 2008 that was conducted in female patients in Malatya, T. vaginalis infection was detected at $4.6 \%$ from vaginal discharge samples on performing microscopy and culture methods in 2008. These results show that there is a need for standard routine diagnostic assays such as nested PCR for the correct and timely treatment as well as for the control of trichomoniasis.

The presence of more than five leucocytes and more than three erythrocytes in urine sediments of patients under a high-power $(400 \times)$ microscopic field is accepted as urinary tract infection respectively. One of the reasons for microscopic hematuria is urinary tract infection (15-16). In the present study, according to white and red blood cell counts in urine, 47 out of the 138 patients tested positive for urinary tract infection. Fisher's exact Test results revealed a statistically significant relationship between urinary tract infection and nested PCR positivity $(p=0.003)$ (Table $1,2)$. There were two T. vaginalis-positive patients without urinary tract infection. Urine analysis of one of them was negative for leucocytes and erythrocytes and accepted as asymptomatic infection. The other patient showed three leucocytes and seven erythrocytes, which can be a sign of suspected urinary tract infection. There is a requirement for conduction further studies with trichomoniasis patients to understand the relationship between laboratory analyses and trichomoniasis.

Male trichomoniasis can be a source of infection for the partner, and trichomoniasis has been implicated as a significant risk factor for the sexual transmission of HIV and other possible STIs as well as of cervical cancer (2-4).

\section{CONCLUSION}

Direct microscopic, culture and Nested PZR methods were applied to investigate the presence of $\mathrm{T}$. vaginalis in urine specimens of working male patients and it was concluded that Nested PZR method is more sensitive than the other methods. Although the PZR method is an expensive method, it improves the diagnostic sensitivity and makes the hidden carriers in the community more open to treatment of more cases. In addition, asymptomatic persons should also be screened to remove those affected, to determine the actual prevalence of the disease in the population, it is recommended for taking precautions.

Ethics Committee Approval: Ethics committee approval was received from Malatya Universitesi, Medical Faculty of the Ethics Committee (Decision Date: 2013 Decision No: 149).

Informed Consent: Written informed consent was obtained patient who participated in this study.

Peer-review: Externally peer-reviewed.

Author Contributions: Concept - M.A.;Design - M.A., M.Y.; SupervisionM.Y., M.A., S.T.; Funding - S.T., Y.Ö.; Materials - M.K., M.Y.; Data Collection and/or Processing - M.Y., A.B.K.; Analysis and/or Interpretation - M.Y., M.A.; Literature Review - M.Y.; Writing - M.Y., S.T., M.A.; Critical Review - M.A., S.T.

Conflict of Interest: No conflict of interest was declared by the authors.

Financial Disclosure: The authors declared that this study has received no financial support.

Etik Komite Onayı: Bu çalışma için etik komite onayı Malatya Üniversitesi, Tıp Fakültesi Etik Kurul'undan alınmıştır (Karar Tarihi: 2013 Karar No: 149).

Hasta Onamı: Yazılı hasta onamı bu çalışmaya katılan hastadan alınmıştır.

Hakem Değerlendirmesi: Dış bağımsız.

Yazar Katkıları: Fikir - M.A.; Tasarım - M.A., M.Y.; Denetleme - M.Y., M.A., S.T.; Kaynaklar - S.T., Y.Ö; Malzemeler - M.K., M.Y.; Veri Toplanması ve/veya İşlemesi - M.Y., A.B.K.; Analiz ve/veya Yorum - M.Y., M.A.; Literatür Taraması - M.Y.; Yazıyı Yazan - M.Y., S.T., M.A.; Eleştirel Inceleme - M.A., S.T.

Çıkar Çatışması: Yazarlar çıkar çatışması bildirmemişlerdir.

Finansal Destek: Yazarlar bu çalışma için finansal destek almadıklarını beyan etmişlerdir. 


\section{REFERENCES}

1. World Health Organization. Global incidence and prevalence of selected curable sexually transmitted infections-2008. WHO Library Cataloguing-in-Publication Data, ISBN 9789241503839, Geneva. 2012.

2. Bandea $\mathrm{Cl}$, Joseph K, Secor EW, Jones AL, Sautter RL, Hammerschlag $\mathrm{RM}$, et al. Development of PCR assays for detection of $T$. vaginalis urine specimens. J Clin Microbiol 2013; 51: 1298-300. [CrossRef]

3. Lee JJ, Moon HS, Lee TY, Hwang SH, Ahn MH, Ryu JS. PCR for Diagnosis of Male Trichomonas vaginalis Infection with Chronic Prostatitis and Urethritis. Korean J Parasitol 2012; 50: 157-9. [CrossRef]

4. Soba B, Skvarc M, Maticic M. Trichomoniasis: a brief review of diagnostic methods and our experience with real-time PCR for detecting infection. Acta Dermatovenerol Alp Pannonica Adriat 2015; 24: 7-10. [CrossRef]

5. Kissinger P. Trichomonas vaginalis: a review of epidemiologic, clinical and treatment issues. BMC Infect Dis 2015; 15: 307. [CrossRef]

6. Aral Akarsu G. Investigation of Trichomonas vaginalis in Patients with Nonspecific Vaginal Discharge. Türkiye Parazitol Derg 2006; 30: 19-21.

7. Sönmez Tamer G, Keçeli Ozcan S, Yücesoy G, Gacar G. The Relation Between Trichomoniasis and Contraseptive Methods. Türkiye Parazitol Derg 2009; 33: 266-9.

8. Çulha G, Görür S, Helli A, Akçin S., Kiper AN. The Prevalence of Trichomonas vaginalis in male patients with urethritis who referred to Mustafa Kemal University Hospital Urology Clinic. Turk Hij Den Biyol Derg 2008; 65: 37-41.

9. Ustun $\mathrm{S}$, illter $\mathrm{T}$. Investigation of the Frequency of $\mathrm{T}$. vaginalis in $\mathrm{Pa}$ tients Who Presented at the Urine Laboratory of the Gastroenterology Clinic Türkiye Parazitol Derg, 2004; 28: 83-5.
10. Tanyüksel M, Başustaoğlu AC, Batsallar M, Haznedaroğlu T, Ozyurt M, Gün H. Study of Trichomonas vaginalis'in male patients with nongonococcic urethritis by microscopy, culture (TYM Medium) and latex agglutination test procedure. Türkiye Parazitol Derg 1995; 19 : 340-4.

11. Özbilgin A, Nazlı O, Tuzcuoğlu Y, Özcel MA, Mulazımoğlu N. Trichomoniasis in male nongonococcic urethritis. Türkiye Parazitol Derg 1992; 16: 43-8.

12. Ertabaklar H, Caner A, Döşkaya M, Demirtaş LO, Töz SO, Ertuğ S. Comparison of polymerase chain reaction with wet mount and culture methods for the diagnosis of trichomoniasis. Türkiye Parazitol Derg 2011; 35: 1-5. [CrossRef]

13. Karaman Ü, Karadağ N, Atambay M, Arserim Kaya NB, Daldal N. A Comparison of Cytological and Parasitological Methods in the Diagnosis of Trichomonas vaginalis. Turkiye Parazitol Derg 2008; 32: 309-12.

14. Sakru N, Toz SO, Yetkin AC, Akıncı PC, Kırca U. Increased sensitivity of Trichomonas vaginalis isolation from vaginal secretions by subsequent blind passage of preliminary negative cultures. Diagn Microbiol Infect Dis 2005; 52: 75-6. [CrossRef]

15. Daniels R. Urinalysis: Delmar's guide to laboratory and diagnostic tests. Canada, Cengage Learning 2002: 905-908.

16. Fischbach FT, Barnett Dunning M. Microscopic examination of Urine sediment: A manual of laboratory and diagnostic tests (Ed: Quincy McDonald), 7th ed. USA: Lippincott Williams \&Wilkins, 2004: 207221.

17. Garcia LS. Parasite recovery: Culture Methods, Animal Inoculation, and Xenodiagnosis, In Diagnostic Medical Parasitology, 4th Ed. Washington DC: USA, American Society for Microbiology; 2001: 850-872. 